（4） $m$-及 $\boldsymbol{p}$-タレソールの些的，今以上の試驗に就て其步留を見るに次の如くなる。

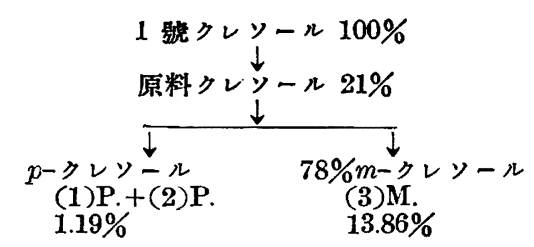

郎ち 1 號クレソールに對して純 $p$-クレソール 1.19\%,78\%mークレソール 13.86\%を得たのである。<smiles>[C]#[W]</smiles>

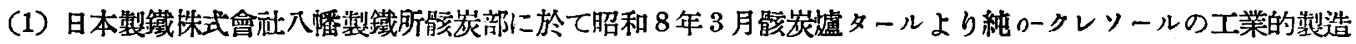
法に成功し著者は其方法を記載した。

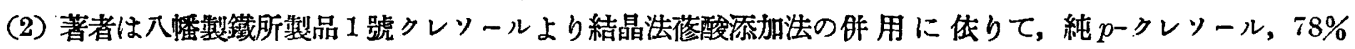
mークレソールの分離を實驗室に於て成功し其方法を記載した。

（3）著者は結晶法或は苳酸法單狍にては純クレンールの分離は可能なりと踓る之を工業的に適用する事は至 難なりと信ず。

（4）著者は結晶法苳酸法に二依る本法を繰返し行ふことにより步留を堌加しp-クレソールの市場の消化力如何 に徏て本方法を以て工業的に成功可能なりと信ず。

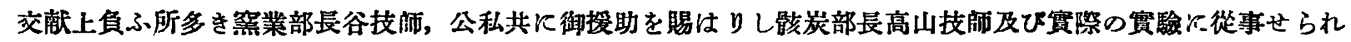
たる松尾，橫山兩氏の諸賢に深く謝意を表するるのである。

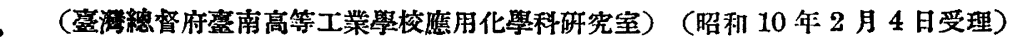

109. 木 蠟 漂白に關す る 研 究(第 2 報)

佐久間 蕞 ・ 百瀨 五十

I. König-Martens スペクトロフォトメーターに依る吸光係數の測定

König-Martens スベクトロフォトメーターを用ひメルク製キシロール溶液となしたる各種木蠟の吸光俰數を 測定したるに次の如き值を得たり。但し $\varepsilon=\frac{\log \tan \alpha-\log \tan \alpha^{\prime}}{\mathrm{kg} / l \times d}$ より計算せり。始に $d$ は觀測管中の可憸 液光線通過距離を $\mathrm{cm}$ にて表はしたるるのなり。

第 1 圖によりて見るに生侅に於ては明かに $6,600 \AA$ 附近に顯著なる吸收あり。是れ著者の 1 人 (佐久間) が 暴に其大略を報告せる所なり（桐生高工學術報告, 第 3 號, 昭和 4, 47)。而して市肘の白蠟に於ては概ね此性 質を失ふもの〉如し（第 2 圖)。

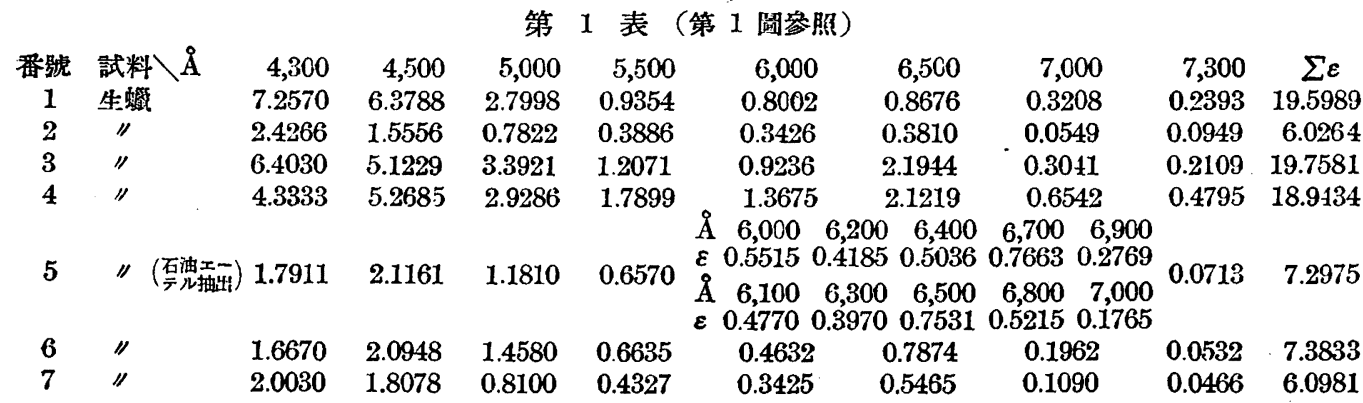




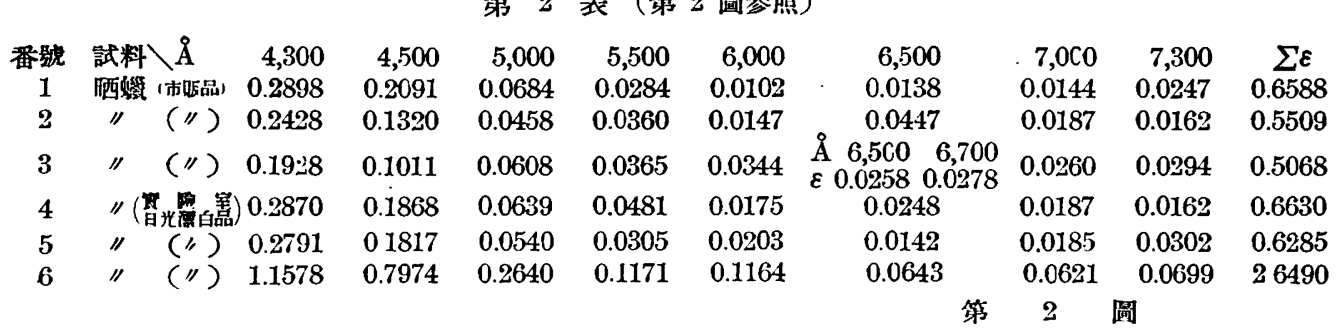
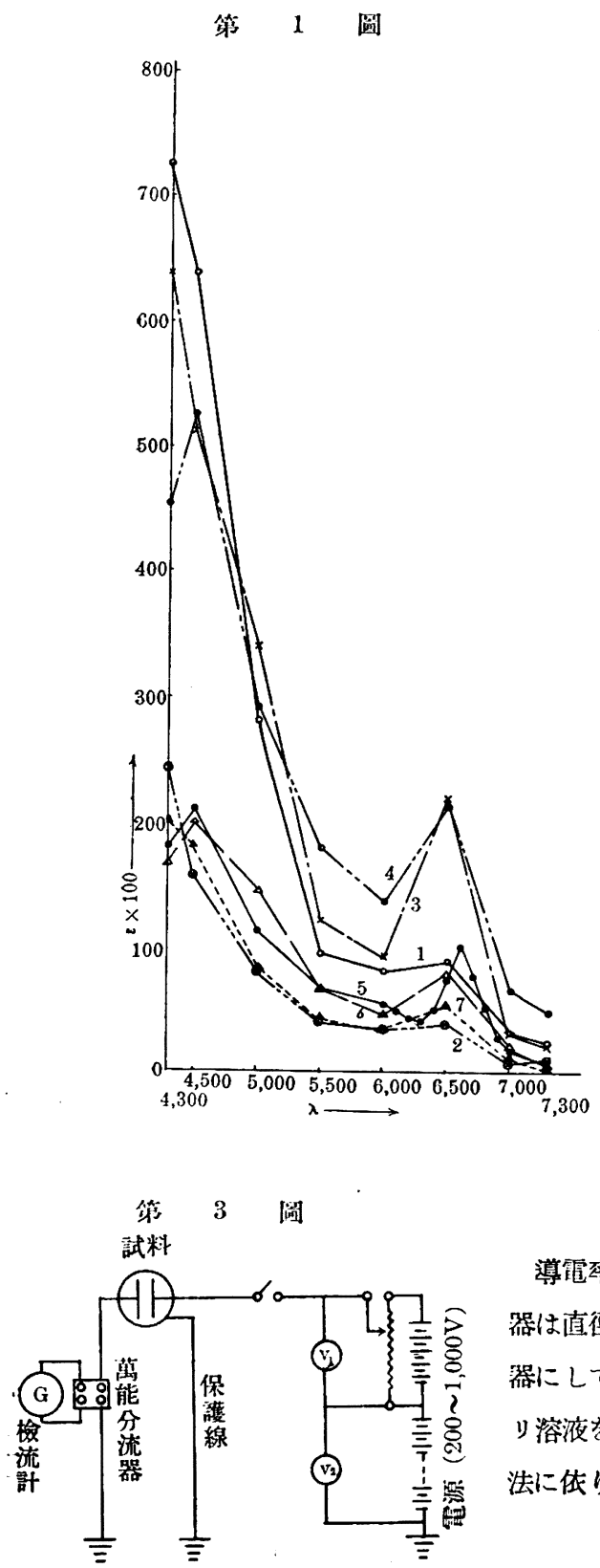

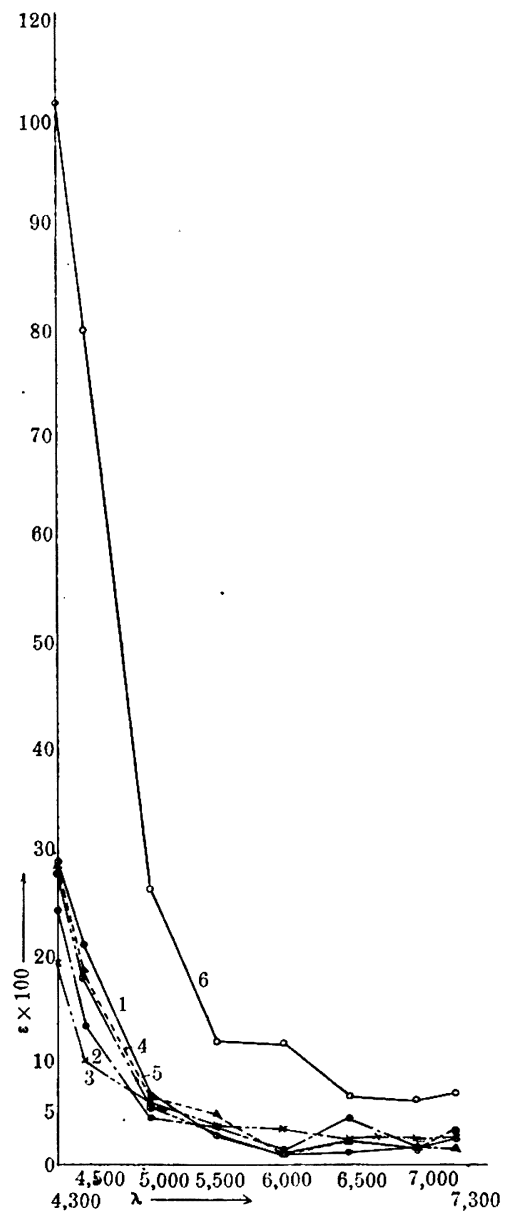

II. 木蠟の導電率测定

導電率の測定は第 3 圖に示す如く直偏法に依れり。圖の試料容 器は直俓 $3 \mathrm{~cm}$, 極板問約 $2 \mathrm{~mm}$ の日金平行電極を有するガラス容 器にして, 導電率の測定に先立ち導電率既知の $N / 100$ 標準監化カ リ溶液を用ひ其のセル恒數を決定し，次で直流電涯を印加し直偏 法に恢り試料の電氣抵抗の測定を行ひ，以て其導電率を算出せり。 


\begin{tabular}{|c|c|c|c|c|c|c|c|c|c|c|}
\hline 試料番㩆 & & & & 青 & 青綠 & 綠 & 黄綠 & 赤 & 導霄率 & $\begin{array}{l}\text { 固有抵抗 } \\
\mathrm{ohm}-\mathrm{cm}\end{array}$ \\
\hline 1 & 生 & & 耧 & 211.0 & 203.0 & 160.0 & 130.0 & 119.7 & $2.78 \times 10^{-10}$ & $3.60 \times 10^{9}$ \\
\hline 2 & & " & & 219.0 & 199.2 & 1461 & 121.2 & 150.0 & $1.18 \times 10^{-10}$ & $8.48 \times 10^{9}$ \\
\hline 3 & 晒 & & 蠉 & 56.0 & 41.0 & 39.9 & 24.7 & 18.6 & $4.59 \times 10^{-11}$ & $2.18 \times 10^{10}$ \\
\hline 4 & & " & & 52.5 & 40.6 & 35.5 & 28.6 & 25.4 & $2.98 \times 10^{-11}$ & $2.36 \times 10^{10}$ \\
\hline 5 & 生 & & 䗾 & 192.5 & 187.2 & 150.6 & 119.7 & 107.3 & $252 \times 10^{-11}$ & $2.97 \times 10^{10}$ \\
\hline 6 & 吕 & $\begin{array}{r}\text {-ボラ } \\
\text { 理 }\end{array}$ & $\begin{array}{l}\text { フイン } \\
\text { 䲆 }\end{array}$ & 211.0 & 189.0 & 160.0 & 126.6 & 113.3 & $2.39 \times 10^{-11}$ & $4.18 \times 10^{10}$ \\
\hline 7 & & $"$ & & 180.8 & 158.5 & 140.3 & 106.4 & 93.9 & $2.39 \times 10^{-11}$ & $4.18 \times 10^{10}$ \\
\hline 8 & & " & & 187.6 & 168.3 & 149.7 & 159.0 & 112.1 & $1.93 \times 10^{-11}$ & $5.17 \times 10^{10}$ \\
\hline 9 & & " & & 185.5 & 171.1 & 142.8 & 110.3 & 106.1 & $1.88 \times 10^{-11}$ & $5.32 \times 10^{\text {to }}$ \\
\hline 10 & & " & & 189.0 & 173.8 & .144 .5 & 115.5 & 103.8 & $1.89 \times 10^{-11}$ & $5.29 \times 10^{10}$ \\
\hline 11 & & " & & 180.2 & 157.0 & 135.8 & 104.9 & 95.8 & $1.88 \times 10^{-11}$ & $5.33 \times 10^{10}$ \\
\hline 12 & & " & & 217.4 & 200.9 & 180.8 & 149.3 & 1329 & $1.83 \times 10^{-11}$ & $5.46 \times 10^{10}$ \\
\hline 13 & & " & & 184.8 & 177.8 & 152.8 & 119.5 & 105.7 & $1.79 \times 10^{-11}$ & $5.60 \times 10^{10}$ \\
\hline 14 & & " & & 184.1 & 166.1 & 144.5 & 119.1 & 126.3 & $1.54 \times 10^{-11}$ & $6.48 \times 10^{10}$ \\
\hline 15 & & " & & 93.6 & 77.2 & 56.0 & 47.6 & 34.0 & $1.46 \times 10^{-11}$ & $6.85 \times 10^{10}$ \\
\hline 16 & & " & & 160.0 & 144.0 & 119.7 & 97.5 & 70.9 & $1.41 \times 10^{-11}$ & $7.11 \times 10^{10}$ \\
\hline 17 & & " & & 171.1 & 154.1 & 132.9 & 104.1 & 78.5 & $1.36 \times 10^{-11}$ & $7.36 \times 10^{10}$ \\
\hline 18 & & " & & 161.1 & 138.2 & 122.8 & 98.6 & 90.6 & $1.35 \times 10^{-11}$ & $7.40 \times 10^{13}$ \\
\hline 19 & & " & & 158.5 & 140.7 & 126.6 & 107.0 & 95.7 & $1.26 \times 10^{-11}$ & $7.92 \times 10^{10}$ \\
\hline 20 & & " & & 138.2 & 93.9 & 105.6 & 86.7 & 74.3 & $1.21 \times 10^{-11}$ & $8.24 \times 10^{10}$ \\
\hline 21 & & " & & 180.8 & 158.5 & 1402 & 106.4 & 93.9 & $1.21 \times 10^{-11}$ & $8.28 \times 10^{10}$ \\
\hline 22 & 硬 & 化 & 油、 & - & - & - & - & - & $1.04 \times 10^{-11}$ & $9.61 \times 10^{10}$ \\
\hline 23 & & $\begin{array}{l}\text { ボラ } \\
\text { 理 }\end{array}$ & & 167.2 & 143.4 & 121.7 & 100.5 & 74.9 & $1.03 \times 10^{-11}$ & $9.72 \times 10^{10}$ \\
\hline 24 & & 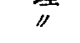 & & 101.6 & 86.2 & 70.9 & 49.2 & 42.8 & $1.01 \times 10^{-11}$ & $9.95 \times 10^{10}$ \\
\hline 25 & & " & & 144.5 & 126.2 & 109.4 & 93.6 & 82.5 & $6.45 \times 10^{-12}$ & $1.55 \times 10^{11}$ \\
\hline 26 & & " & & 145.3 & 119.7 & 97.1 & 70.7 & 49.2 & $5.84 \times 10^{-12}$ & $1.71 \times 10^{1 k}$ \\
\hline 27 & & " & & 149.1 & 134.4 & 113.2 & 83.3 & 60.4 & $5.34 \times 10^{-12}$ & $1.87 \times 10^{11}$ \\
\hline 28 & & " & & 117.1 & 98.1 & 78.7 & 58.7 & 50.0 & $4.15 \times 10^{-12}$ & $2.41 \times 10^{11}$ \\
\hline 29 & & " & & 119.4 & 103.3 & 83.4 & 61.3 & 47.3 & $3.97 \times 10^{-12}$ & $2.52 \times 10^{11}$ \\
\hline 30 & & " & & 133.4 & 119.1 & 92.9 & 68.1 & 50.0 & $2.97 \times 10^{-12}$ & $3.37 \times 10^{11}$ \\
\hline 31 & & " & & 122.1 & 101.1 & 811.6 & 55.4 & 45.5 & $2.94 \times 10^{-12}$ & $3.40 \times 10^{11}$ \\
\hline 32 & & " & & 101.6 & 88.7 & 67.0 & 50.8 & 42.8 & $246 \times 10^{-12}$ & $4.07 \times 10^{11}$ \\
\hline 33 & & " & & 118.1 & 96.2 & 77.2 & 57.0 & 42.7 & $1.92 \times 10^{-12}$ & $5.20 \times 10^{11}$ \\
\hline 34 & & " & & 113.3 & 96.2 & 73.0 & 57.7 & 46.0 & $1.29 \times 10^{-12}$ & $7.77 \times 10^{11}$ \\
\hline 35 & & " & & 114.9 & 96.2 & 73.0 & 55.9 & 50.8 & $1.14 \times 10^{-12}$ & $8.78 \times 10^{11}$ \\
\hline 36 & & " & & 70.5 & 49.0 & 38.6 & 23.4 & 21.6 & $1.09 \times 10^{-12}$ & $9.19 \times 10^{11}$ \\
\hline 37 & & " & & $1 \mathrm{CO} 0$ & 83.9 & 62.9 & 47.8 & 36.9 & $1 . c 6 \times 10^{-13}$ & $9.46 \times 10^{11}$ \\
\hline 38 & & " & & 107.3 & 93.6 & 73.0 & 61.3 & 47.6 & $1.03 \times 10^{-12}$ & $9.70 \times 10^{11}$ \\
\hline 39 & & " & & 101.6 & 69.5 & 53.5 & 38.7 & 38.7 & $9.44 \times 10^{-13}$ & $1.06 \times 10^{12}$ \\
\hline 40 & & " & & 91.1 & 73.6 & 58.9 & 46.8 & 42.8 & $8.87 \times 10^{-13}$ & $1.13 \times 10^{12}$ \\
\hline 41 & & " & & 134.0 & 111.8 & 86.2 & 63.1 & 52.5 & $8.33 \times 10^{-13}$ & $1.20 \times 10^{12}$ \\
\hline 42 & & " & & 71.7 & 55.6 & 43.3 & 32.7 & 27.3 & $8.00 \times 10^{-13}$ & $1.25 \times 10^{1}=$ \\
\hline 43 & & " & & 82.1 & 65.8 & 51.3 & 40.9 & 37.0 & $7.35 \times 10^{-13}$ & $1.36 \times 10^{12}$ \\
\hline 44 & & " & & 89.4 & 72.6 & 62.9 & 45.5 & 39.8 & $7.35 \times 10^{-13}$ & $1.36 \times 10^{12}$ \\
\hline 45 & & " & & 91.1 & 75.1 & 61.3 & 47.6 & 32.6 & $671 \times 10^{-13}$ & $1.49 \times 10^{12}$ \\
\hline 46 & & " & & 85.7 & 60.0 . & 53.7 & 34.0 & 30.3 & $6.54 \times 10^{-13}$ & $1.53 \times 10^{12}$ \\
\hline 47 & & " & & 93.6 & 79.4 & 67.0 & 44.4 & 35.5 & $6.37 \times 10^{-13}$ & $1.57 \times 10^{12}$ \\
\hline 48 & & " & & - & - & - & - & - & $5.92 \times 10^{-13}$ & $1.69 \times 10^{12}$ \\
\hline 49 & & " & & 89.9 & 77.2 & 57.7 & 42.8 & 34.0 & $5.74 \times 10^{-13}$ & $1.74 \times 10^{12}$ \\
\hline 50 & & " & & 91.1 & 77.2 & 631 & 46.0 & 38.4 & $4.55 \times 10^{-13}$ & $2.20 \times 10^{12}$ \\
\hline 51 & & " & & - & - & -- & - & - & $4.18 \times 10^{-13}$ & $2.39 \times 10^{12}$ \\
\hline 52 & & " & & 126.6 & 101.6 & 90.9 & 63.1 & 44.4 & $3.95 \times 10^{-13}$ & $2.53 \times 10^{12}$ \\
\hline 53 & & テアリ & ン酸 & - & - & - & - & - & $3.91 \times 10^{-13}$ & $2.56 \times 10^{12}$ \\
\hline 54 & 固 & 柇パラ & フィン & - & 一 & - & - & - & $3.65 \times 10^{-13}$ & $2.74 \times 10^{12}$ \\
\hline
\end{tabular}


郎ち

$K$ 七 恒 僌

$R$ 鵤料の抵抗湘定值 $\mathrm{ohm}$

$R$ s 標潐液の抵抗测定值 ohn（交流ブリッヂ法に依る）

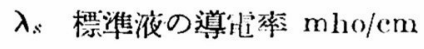

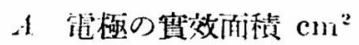

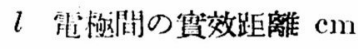

$\lambda$ 韩料の導電率

とすれば $\lambda$ は次の如くして算山し得ぐし。

$$
K=l / A=R s \cdot \lambda s \mathrm{~cm}^{-1}, \quad \lambda=K / R \mathrm{mho} / \mathrm{cm}
$$

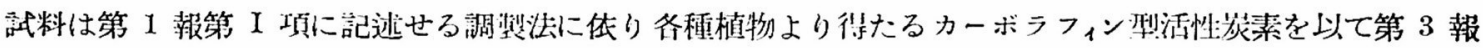

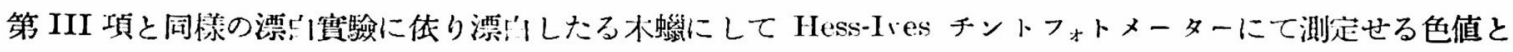
作記せり。(第 3 㤗)

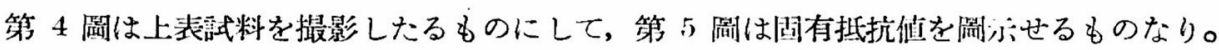
第 + 阔

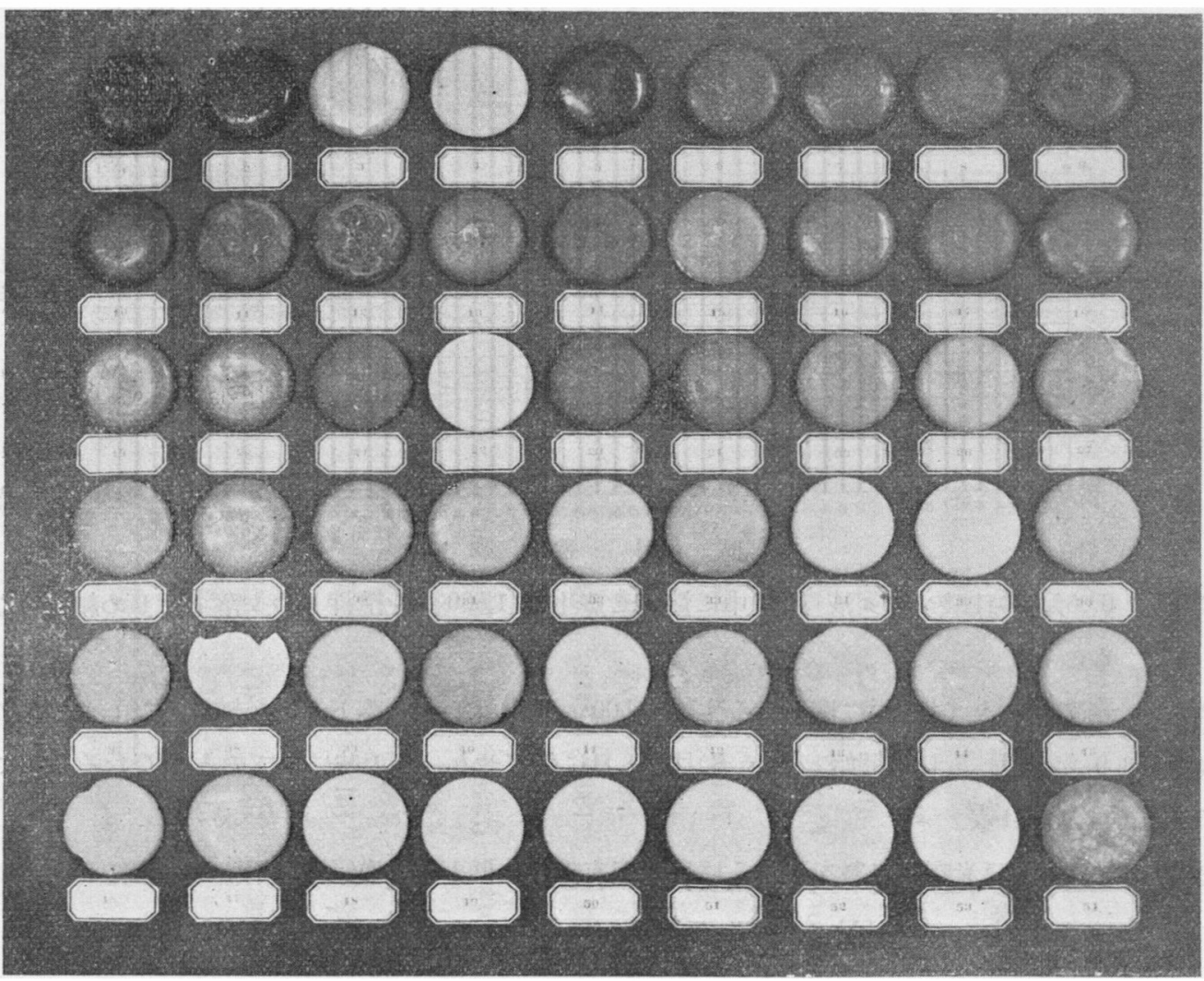

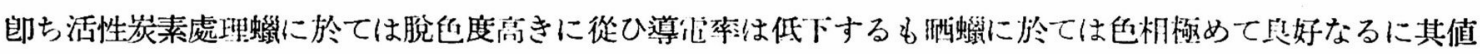
高し。是れて䄽蠟が單なる脫芭蛀にあらざる一登たり得べし。

\section{III. 日光曝露中に於けっ導電率の變化}

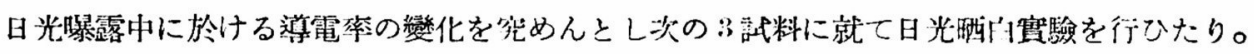

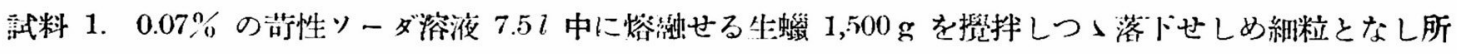
拥蠉花とせるもの。 


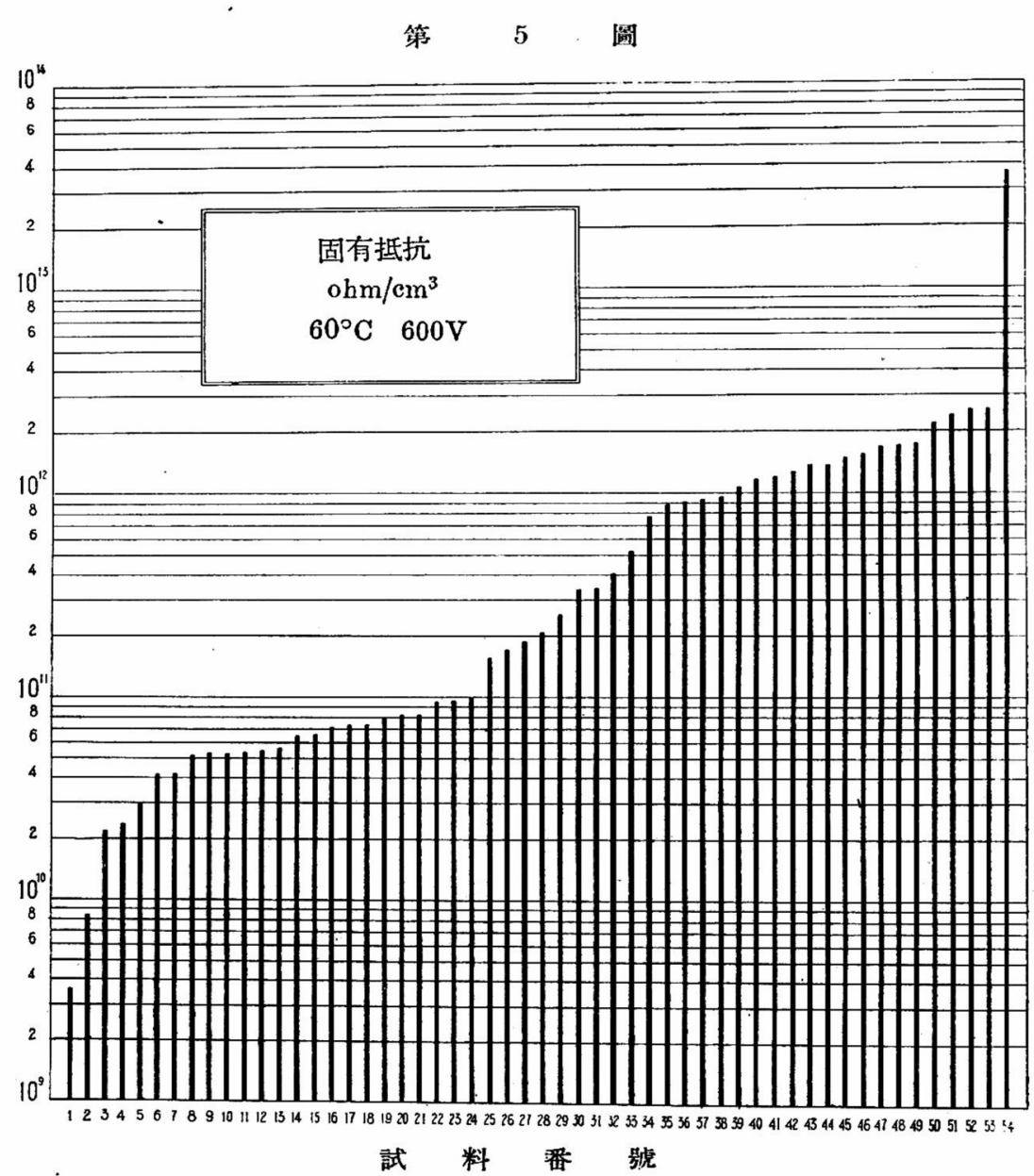

試料 2. $0.05 \%$ の珪酸ソーダ夜 $7.5 l$ 中に熔融せる生蠟 $1,500 \mathrm{~g}$ を挸找しつ\落下せしめ細粒となしたる むの。

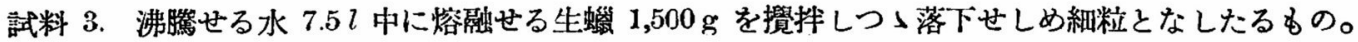
實驗は昭和 9 年 7 月 5 日に開始し同年 8 月 30 日に終了せり。晴天時に於てのみ行ひたるを以て曝露日 數は 35 日なり。(第 4 表)

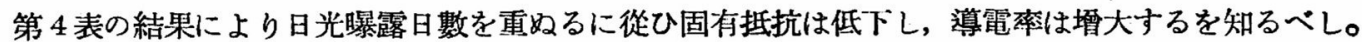

$$
\text { IV. 酸化酸之導電率の關 係 }
$$

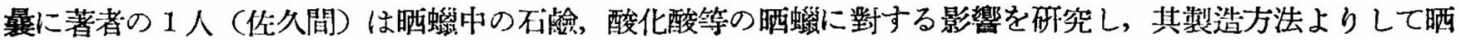
蠟中に赏然会有せらるべき不蝓及酸化酸は其粘度を增加する因子たるを證明せり（桐生高工學術報告,第 3 號 昭和 4,148 )

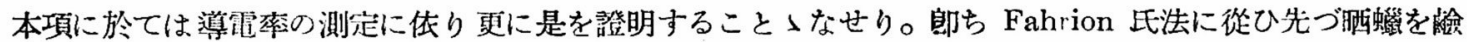
化し酸を以て分解し，得たる脂肪酸は不油エーテル（沸默 $70^{\circ} \mathrm{C}$ 以下) にて處理し酸化酸を除去したるものと 其然らざるものとに分別し導電率を比較したるに第 5 表の如き結果を示せり。

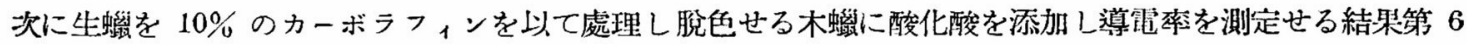




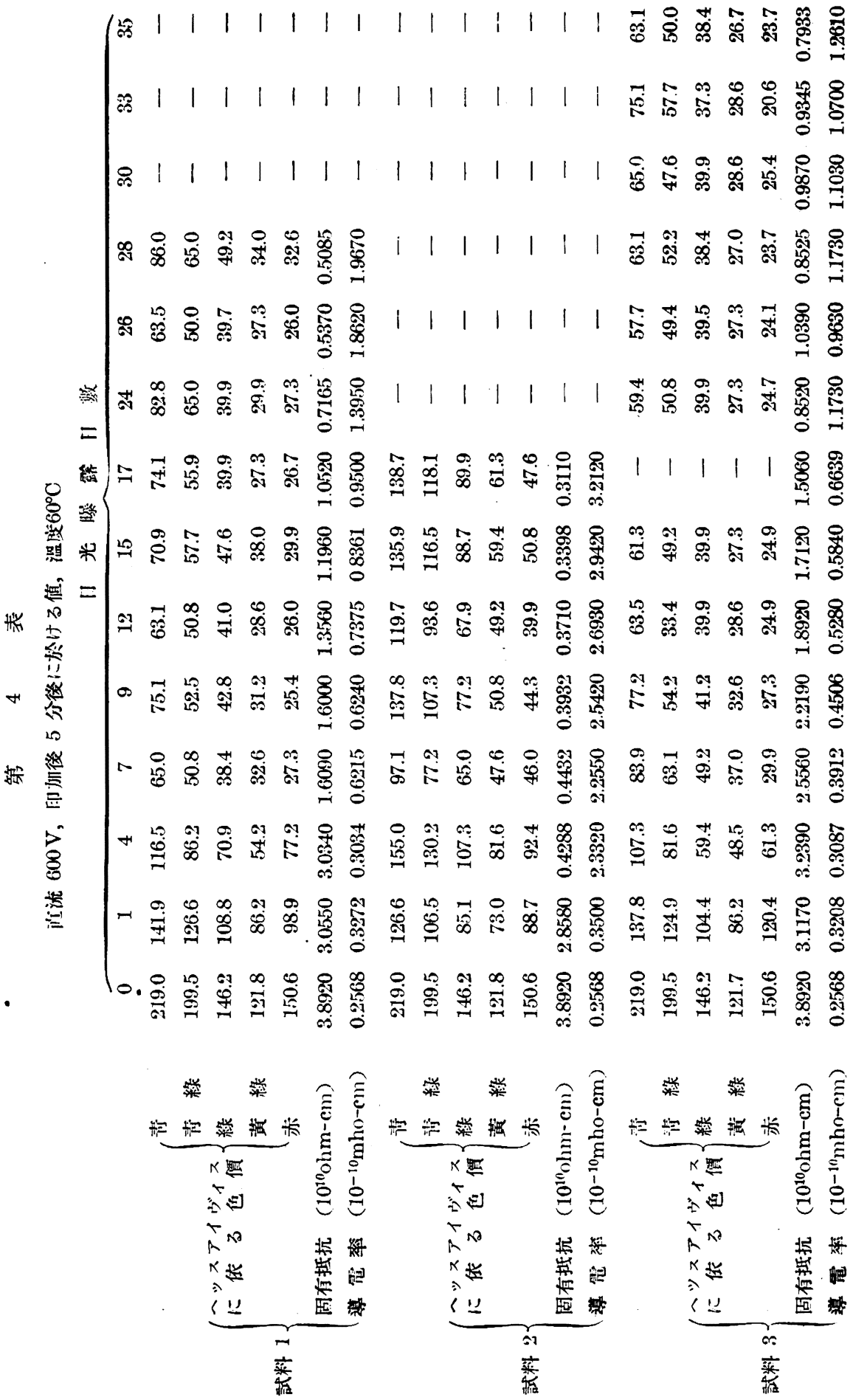


表の如し。但し上表實驗と同㨾に行ひしも溫度は $60^{\circ} \mathrm{C}$ となし, 酸化酸は Hazura 氏法に㑈りメルク製オレイ ン酸より調製せり。

第 5 表

直流 $600 \mathrm{~V}$, 印加後 1 分目に於ける值，溫度 $70^{\circ} \mathrm{C}$

理 法

酸化酸を除去せざるもの 酸化酸を除去したるるの

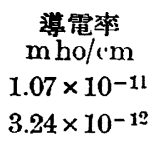

第 6 表

\begin{tabular}{|c|c|c|c|c|c|}
\hline 酸化酸添加量 \% & $\begin{array}{l}\text { 導電 染 } \\
\text { mho/cm }\end{array}$ & $\begin{array}{l}\text { 固有抵抗 } \\
\text { ohm-cm }\end{array}$ & 酸化酸添加量 \% & $\begin{array}{l}\text { 導蕓率 } \\
\text { mho/cm }\end{array}$ & $\begin{array}{l}\text { 固有抵抗 } \\
\text { ohm-cm }\end{array}$ \\
\hline 0.00 & $0.978 \times 10^{-12}$ & $10.230 \times 10^{11}$ & 0.50 & $3.990 \times 10^{-12}$ & $2.510 \times 10^{11}$ \\
\hline 0.03 & $1.030 \times 10^{-12}$ & $9.720 \times 10^{11}$ & 0.80 & $5.380 \times 10^{-12}$ & $1.860 \times 10^{11}$ \\
\hline 0.10 & $1.270 \times 10^{-12}$ & $7.880 \times 10^{11}$ & 1.00 & $12.000 \times 10^{-12}$ & $0.834 \times 10^{11}$ \\
\hline 0.30 & $2.340 \times 10^{-12}$ & $4.280 \times 10^{11}$ & & & \\
\hline
\end{tabular}

$$
\begin{array}{r}
\text { 固有抵抗 } \\
\text { ohm-cm } \\
9.35 \times 10^{10} \\
3.08 \times 10^{11}
\end{array}
$$

郎ち酸化酸は導電率を堙加せしむること明かにして更に添加量と並行的關倸あるを知れり。

\section{V. 石 䲓と導 電 率}

著者等は更に石羷と導電率との關係を知らんとし生蠟にカーボラフィン $10 \%$ を添加し $100^{\circ} \mathrm{C}$ に於て 2 時間

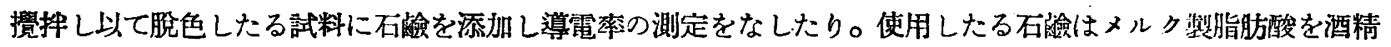
に溶解しフェノールフタレインを指示繤として $N / 2$ 酒精性苛性りーダを以て中和し，炭酸ガスにて過剩のア ルカリを除き，酒精より結晶せしめたるものを $40^{\circ} \mathrm{C}$ に於て傎空乾燥を行ひたるものなり。

$$
\text { 第 } 7 \text { 表 }
$$

㨁流 $600 \mathrm{~V}$, 印加後 5 分後に於ける值, 溫度 $60^{\circ} \mathrm{C}$

石撂添加 \%

0
0.1
0.5

パルミチン酸カリ
$1.68 \times 10^{-12}$
$4.95 \times 10^{-12}$
$694 \times 10^{-12}$

尊電染 $(\mathrm{mho} / \mathrm{cm})$

$\begin{array}{cc}\text { ステマリン酸カリ } & \text { オレイン酸カリ } \\ 1.68 \times 10^{-12} & 1.68 \times 10^{-12} \\ 4.13 \times 10^{-12} & 4.15 \times 10^{-12} \\ 9.25 \times 10^{-12} & 8.47 \times 10^{-12}\end{array}$

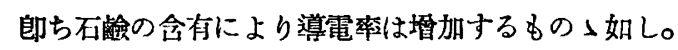

總括

1. 生螠中の色素は $6,600 \AA$ 附近に極大の吸收あり，然れども日光曝露中是を失ふことを知れり。

2. 各種木蠟の導電萃を湘定し,カーボラフィンを以て漂白せるものは脫色と同時に電導率の低下を來すも 天日漂白に於ては脫色せらるっと踓も導電率は依然として高值を示せり。

3. 日光曝露中に於ける木蠟の導電率を檢したるに脫色と並行的關係あるを知れり。

4. 酸化酸は木蠟の導電率を㴰加す。

5. 石捡亦同樣なり。

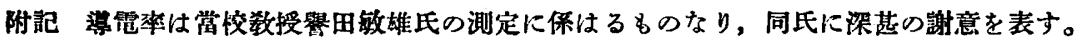

